$$
\begin{array}{cccc}
\text { S sciendo } & \text { International Conference KNOWLEDGE-BASED ORGANIZATION } \\
\text { Vol. XXV } & \text { No } 1 & 2019
\end{array}
$$

\title{
TACTICAL VARIABLES - A TOOL FOR MISSION ANALYSIS
}

\author{
Michal HRNČIAR
}

\section{Armed Forces Academy of "General Milan Rastislav Štefánik", Liptovský Mikuláš, Slovakia, michal.hrnciar@aos.sk}

\begin{abstract}
Military operations have an evolving character that responds to the changes in the nature of the conflict. The basic nature of the operation is given by the operational themes. These have a major impact on related military activities and on their tactical tasks. The commander at the tactical level, in order to achieve the end state of the operation, must fully understand the mission, respect the superior's intent and perceive the conditions, circumstances and influences of each individual characteristic element of the assigned area of operation. The instruments to achieve this status of comprehension are tactical variables (Mission, Enemy, Terrain and Weather, Troops available, Time available, Civil considerations - METT-TC). The aim of the article is to describe tactical variables, which at the tactical level serve as the tool for mission analysis.
\end{abstract}

Keywords: mission variables, mission, enemy, terrain and weather, civil considerations

\section{Introduction}

While the analysis of the operational variables (Political, Military, Economic, Social, Information, Infrastructure, Physical, Time - PMESII-PT) executed at the operational and strategic level improves the understanding of the operating environment (OE), [1] it does not provide detailed information that is necessary to perform a specific operation in a particular area of operation (AOO) [2]. For a more detailed analysis of the information related to the planned operation, commanders at tactical command and control level use the tactical variables (Mission, Enemy, Terrain and Weather, Available Time, Civil Considerations - METT-TC) [3].

\section{Tactical variables}

The analysis and evaluation of individual tactical variables enables commanders at a tactical level to understand and visualize their role in the context of a specific AOO. The commanders constantly face adapting enemies, varying views of the public and contradictory priorities of various nonmilitary organizations in AOO [4]. The use of tactical variables combined with the knowledge of operational variables enable the commander to understand the threats and the resulting risks, to anticipate the consequences of the operation, and thus to understand the implications of the operation and to act effectively within AOO. Currently the existing conflicts, military and non-military, are mostly of a non-linear nature, where units composed of multiple specializations, both smaller and acting independently prevail [5].

Consequently, it becomes a challenge for the whole military community, especially when it comes to preparing the "boots on the ground" [6].

\subsection{Mission}

Mission represents "a clear, concise statement of the task of the command and its purpose" [7]. The mission thus defines 
the tactical tasks for subordinate units, and at the same time specifies the purpose of these tasks. The "5 W" rule applies when formulating the mission by specifying Who, What, When, Where and Why the unit should perform. The commander does not regulate "how" the task should be fulfilled. In the framework of the mission command, which emphasizes the initiative of the subordinate commanders, the choice of the way of executing the task is within the competence of the respective subordinate commander [8].

The tactical task determines the activity to be performed and the effect to be achieved by this activity. In their expression, meaningful verbs are used, e.g. attack, destroy, divert, disrupt, seize, block, retain, clear, secure and others (Picture 1).

At the same time, all tactical tasks have their graphic representation in the form of tactical symbols.

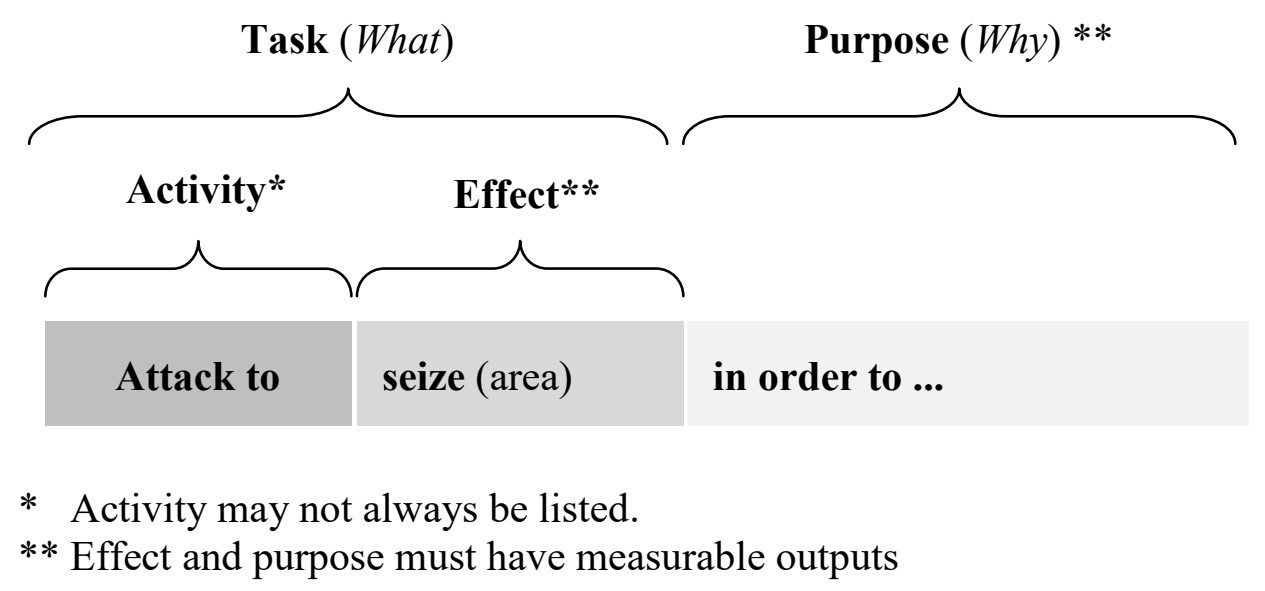

Picture 1 Mission statement structure [8]

The "Secure - Shape - Develop" operational framework is applied at the tactical level. This framework provides an appropriate orientation in the assignment of specific tactical tasks to military units (through task verbs) while at the same time emphasizing the concurrency of tactical tasks that are typical of contemporary operations.

\subsection{Enemy}

An analysis of the enemy must be aimed at identifying the basic information about their composition, activity, deployment, disposition (strengths and weaknesses) and other factors that are covered by the SALUTE acronym (Size, Activity, Location, Unit, Time, Equipment) [3].

\subsection{Terrain and Weather}

The terrain includes the natural terrain features, such as rivers, mountains, meadows, as well as artificial terrain features created by human activities, such as cities, airports, bridges, and others. Weather describes AOO's climate and it is focused on temperatures, air humidity, visibility, wind, precipitation (rain, snow) and cloud at a specific location and at a specific time. Generally, the terrain and weather directly affect the deployment of military capabilities, use of weaponry and equipment and has an impact on observation and mobility [9]. The commander analyses the impact of the terrain and weather on the operation of his unit, as well as on the activity of the enemy. In practice, the analysis of the military aspects of the terrain is realized through an acronym OAKOC (Observation and fields of fire, Avenues of approach, Key terrain, Obstacles, Cover and Concealment): [3]

- Observation and fields of fire are related 
to the analysis of those parts of the terrain that are directly visible from the assumed positions of own units as well as from the enemy. These areas can be covered by direct artillery fires, but also by fire from small arms (danger of sniper actions);

- Avenues of approach are the avenues that lead to the object or the key terrain. These are considered in terms of their accessibility and pass ability. The categories are not restricted, restricted, severely restricted;

- Key terrain is the area or point whose occupation, retention or control is an advantage for one of the combatants' sides;

- Obstacles include all natural or artificial objects that prevent or complicate the manoeuvre (steep slopes, forest vegetation, watercourses, dams, urban areas, minefields, etc.).

- Cover and Concealment are those parts of the terrain that provide protection against direct fire (terrain waves, gorges, etc.). Concealment protects only from observation, but does not provide protection against the effects of fire (forest vegetation, bushes and others).

\subsection{Troops available}

This tactical variable factor represents the combat power of a particular unit expressed by human power, its moral state, its level of training and experience. Additionally it includes the species, the number and status of equipment, ammunition and supplies [10]. The commander shall specify the strengths and weaknesses of his unit through analysis, in relation to the particular conditions of the operation. If Close Air Support (CAS) is requested during the mission, the Joint Terminal Attack Controller (JTAC) must always provide to the commander and key staff [11] a detailed explanation of the type of deployment and reason for choosing it. A similar analysis applies to all units and means that support or reinforce its unit, including all the actors involved.

\subsection{Time available}

Time available is a time-spatial aspect of the preparation and implementation of a particular operation. Operations that predominate in stability activities and their tasks (operations within operational theme Security, e.g. Counterinsurgency operations - COIN) generally require significantly longer time than other operations.

\subsection{Civil considerations}

In current operations, notably in nonconventional/irregular warfare, the host nation is a vital factor because the advantage of the conflict is that of the indigenous people. As a result, the civil aspects represent the most important tactical variable factor that requires indepth analysis and evaluation. It concerns the consideration of the impact of civilian institutions and civilian authorities, the views and reactions of the local population, as well as the ROE restrictions that have a complex impact on the operation and its resulting impact on the overall campaign. The possibility of successfully interacting with the external surrounding environment can be fulfilled only in the conditions ofa sound internal management, able to manage the surrounding external issues. [12]It includes six areas that are labelled with an acronym ASCOPE (Areas, Structures, Capabilities, Organizations, People, and Events): [13]

- Areas represent specific areas (locations) in AOO where individual demographic groups live (e.g. tribal, religious, economic, political, and other);

- Structures consist of important structures (bridges, road networks, power stations, churches, mosques, hospitals, cultural monuments and others) located in the AOO. Analysis of these structures involves identifying how their location, function and facilities can support a particular operation;

- Capabilities represent the capabilities of local authorities to provide local people with key services, such as public 
administration, security, healthcare, etc. The analysis of this area is aimed at identifying the needs of the local population, its security, and availability of health care, education, living standards and so on. This analysis also provides the basis for identifying the causes of the crisis (conflict);

- Organizations are civilian groups or institutions deployed in the AOO, which cooperate with the local population and military units. Their goal is to provide financial or logistical support. Some organizations may come from the internal environment (local tribes, ethnic, religious, patriotic or political groups, etc.), others from external areas outside of AOO (transnational corporations, GOs, NGOs, and others);

- People include the civilian population located in the AOO or Area of Interest (AI), whose activities and views may affect the operation. An important aspect of this factor is the communication channels that allow the flow of information between the local populations. These include visual signals (graffiti, posters, billboards, paintings, videos, television broadcasts, etc.) or acoustic methods of information dissemination (legal and illegal broadcasting, amplification of information from minarets or squares, religious manifestations and education);

- Events include events or aspects of public or private life, routine, cyclical, planned or spontaneous activities (celebrations, national or religious holidays, harvest celebrations, elections, civil unrest, etc.) affecting the people, the organizational activity and military operations;
During the Intelligence Preparation of the Battle space (IPB), the tactical commander and his staff analyse the civil aspects from three perspectives: from the perspective of the local population, the enemy and their own forces. Its purpose is to determine the impact of the civil aspects on the course of action of its own forces and of the enemy.

\section{Conclusions}

METT-TC tactical variables are a tool for achieving a detailed analysis and assessment of the conditions, circumstances and impacts of individual factors specific of a particular AOO. They include factors such as Mission, Enemy, Terrain and Weather, Troops available, Time available, Civil consideration (METT-TC)[3]

The METT-TC analysis tool allows tactical commanders to get a detailed picture of AOO. This is directly related to the capability of the commander to apply knowledge about existing or potential threats and risks (regular military force, aggressive non-state actors, etc.) during the planning process. It helps to understand the physical environment, the forces, the time, and the impact of the local population and other friendly, neutral and hostile actors operating in the AOO (government agencies, non-governmental and international organizations, police and security forces and others).

This tool is also useful for designing the pre-deployment training or battle rehearsal on the lowest tactical level. [14]This pertinent knowledge interferes with the possibilities, limits the capabilities and influences the execution of military activities and individual tactical tasks necessary to achieve the end state of the operation.

\section{References}

[1] Spilý, P. Insight into contemporary operational environment. In: Security Dimensions: international \& national studies. ISSN 2353-7000, No. 11, pp. 132-140, 2014. 
[2] Marek, J. Globalizácia ako aktér medzinárodnej bezpečnosti 21. storočia (in Slovak). In: National and International Security 2017: Proceedings of 8th International Scientific Conference, ISBN 978-80-8040-551-9, pp. 297-303, Liptovský Mikuláš, Slovak Republic, October, 2017.

[3] Hrnčiar, M. Možnosti zvýšenia efektívnosti operácii proti povstaniu (in Slovak). [Dissertation Thesis]. Liptovský Mikuláš, Slovak Republic, 2017.

[4] Wesselényi, J., Kompan, J. Miesto a úlohy medzinárodného kurzu štábnych dôstojníkov (ISOC) v rámci kariérneho a odborného vzdelávania v OS SR a NATO (in Slovak). In: Vojenské reflexie. ISSN 1336-9202, Vol. 13, No. 1/2018, pp. 44 - 55, 2018.

[5] Bučka, P., Andrassy, V. Military education and training supported by blended simulation. In: The 23rd International Conference. The Knowledge-Based Organization: management and military sciences. ISBN 978-973-153-273-8, pp. 61-65, Sibiu, Romania, June, 2017.

[6] Majchút, I. Deployability of armed forces in irregular warfare. In: The 24th International Conference. The Knowledge-Based Organization: Conference proceedings 1. Management and Military Sciences. ISBN 978-973-153-325-4, pp. 130-136, Sibiu, Romania, June, 2018.

[7] STANAG 3680 AAP-6 NATO Glossary of Terms and Definitions. Edition 2017.

[8] Spilý, P., Hrnčiar, M. Vojenská taktika (in Slovak). ISBN 978-80-8040-471-0, Liptovský Mikuláš, The Armed Forces Academy of General Milan Rastislav Štefánik, Slovak Republic, 2013, 272 pp.

[9] Hrnčiar, M. The Counterinsurgency Operating Environment. In: The 24th International Conference. The Knowledge-Based Organization: Conference proceedings 1. Management and Military Sciences. ISBN 978-973-153-325-4, pp. 87-92, Sibiu, Romania, June, 2018.

[10] Varecha, J. Možný pohl'ad na parameter bojového potenciálu (in Slovak). In: National and International Security 2016: Proceedings of $7^{\text {th }}$ International Scientific Conference. ISBN 978-80-8040-534-2, pp. 569-577, Liptovský Mikuláš, Slovak Republic, October, 2016.

[11] Turaj, M., Zhodnotenie aktuálneho stavu bojového použitia predsunutých leteckých navádzačov $v$ podmienkách ozbrojených síl Slovenskej republiky (in Slovak). In: Vojenské reflexie. ISSN 1336-9202, Vol. 13, No. 2/2018, pp. 164 - 174, 2018.

[12] Nečas, P., Andrassy, V. Diplomatic missions' order versus security and sustainability. In: Journal of Security and Sustainability Issues. ISSN 2029-7017 (print), ISSN 20297025 (online). Vol. 8, No. 2, pp. 267-276, 2018.

[13] FM 3-24.2 Tactics in Counterinsurgency. Washington, DC: Headquarters, Department of the Army, 2009, $300 \mathrm{pp}$.

[14] Zahradníček, P. Centralizace výcviku $k$ nasazení do zahraničních operaci jako príležitost (in Czech). Economics and Management. ISSN 802-3975, No. 1/2018, pp. 54-60, 2018. 